\title{
Repellency of Neem Oil against Red Rust Flour Beetle, Tribolium castaneum Herbst, (Coleoptera:Tenebronidae) and Lesser Grain Borer, Rhyzopertha dominica (Fabricius) (Coleoptera: Bostrichidae)
}

\author{
Rashmi Joshi*, Neeta Gaur, Ashish Devrani and Mritunjoy Barman \\ Department of Entomology, College of Agriculture, GBPUA\&T, \\ Pantnagar, Uttarakhand, India
}

*Corresponding author

A B S T R A C T

\begin{tabular}{|c|}
\hline Keywords \\
\hline $\begin{array}{l}\text { Repellency, Neem } \\
\text { oil, Rhyzopertha } \\
\text { dominica, } \\
\text { Tribolium } \\
\text { castaneum }\end{array}$ \\
\hline Article Info \\
\hline $\begin{array}{l}\text { Accepted: } \\
\text { 07 December } 2018 \\
\text { Available Online: } \\
\text { 10 January } 2019\end{array}$ \\
\hline
\end{tabular}

\section{Introduction}

T. castaneum is one of the key pest of stored products and stored grains throughout the world (Sinha and Walters, 1985) and the Lesser grain borer, $R$. dominica, is one of the most important internal feeders of stored grains (Chanbang et al., 2007). $R$. dominica, a primary coloniser of stored products is capable of infesting stored grain kernels easily, while grain kernels, flour or grains already infested by primary coloniser (Vayias et al., 2010). Fumigation plays a major role in insect pests' elimination in stored products. Currently phosphine and methyl bromide are two common fumigants used for stored product protection world over. Insect resistance to phosphine is a global issue now and control failures have been reported in field situations in some countries (Taylor, 1989; Collins et al., 2002). Methyl bromide, a broad spectrum fumigant, has been declared as ozone depleting substance and therefore, is being phased out completely.

With the high cost of synthetic products and the current lack of effective pesticides for stored-product protection, evaluation of local 
plant as sources of protectants is very desirable to help farmers use locally available and environment friendly products to limit post-harvest losses of their produce (Bouda et al., 2001). It is already well established that the seeds of neem contain compounds that can control over 100 species of insects, mites and nematodes on field and vegetable crops (Ahmed and Grainage, 1985). Some of these compounds have been found to be effective against many species of stored product Coleoptera (Grainage et al., 1985). The most important compound is a triterpenoid, Azadirachtin, although other compounds such as nimbin, nimbidin and salanin are also found. These compounds possess insecticidal, ovicidal, antifeedant and growth inhibiting effects against many spp. of insect pests (Stoll, 1988; Vietmeyer, 1992). Many neem based products are approved for use as organic insecticides and marketed. The present study was therefore undertaken to evaluate the repellent activity of neem oil against $R$. dominica and T. castaneum.

\section{Materials and Methods}

\section{Essential oil}

Oils selected for the study were extracted from the locally available plants by steam distillation at Medicinal and Aromatic Plants Research and Development Centre, Pantnagar.

\section{Method for repellency test}

Repellency test was conducted following the method of Talukdar and Howse (1993). Petri dishes $9 \mathrm{~cm}$ in diameter were used to confine insects during experiment. The essential oils were diluted in ethanol to different concentrations $(1.0 \%, 2.0 \%$ and $3.0 \%)$ and absolute ethanol was used as control. Filter paper with a $9 \mathrm{~cm}$ diameter was cut in half and $1 \mathrm{ml}$ of each concentration was applied separately to one half of the filter paper as uniformly as possible with a micropipette. Another half (control) was treated with $1 \mathrm{ml}$ of absolute ethanol. Both the treated half and the control half were then air dried to evaporate the solvent completely. A full disc was carefully remade by attaching the treated half to the control half with tape. Care was taken so that the attachment did not prevent free movement of insects from the one half to another, but the distance between the filter paper halves remained sufficient to prevent diffusion of test sample from one half to another. Each remade filter paper was placed in a petri dish. Twenty insects were released in the centre of each filter paper disc and cover was placed over the petri dish. Three replicants were used and experiment was repeated twice. Counts of the insects present on each half were made after every half an hour and up to fifth interval. Percent repellency of each oil was calculated by using the following formula from Abbott (1925):

Percent Repellency $=\frac{\mathrm{A}-\mathrm{B}}{\mathrm{A}} \times 100$

Here,

$\mathrm{A}=$ Average number of insects present on untreated portion

$\mathrm{B}=$ Average Number of insects present on treated portion

The percentages of repellency were then categorized according to the following scale by the method of Roy et al., (2005):

\begin{tabular}{|c|c|}
\hline Class & Repellency Rate $(\boldsymbol{\%})$ \\
\hline $\mathbf{0}$ & $>0.01-0.10$ \\
\hline I & 0.10 to 20.00 \\
\hline II & 20.10 to 40.00 \\
\hline III & 40.10 to 60.00 \\
\hline IV & 60.10 to 80.00 \\
\hline $\mathbf{V}$ & 80.10 to 100.00 \\
\hline
\end{tabular}


Results and Discussion

Repellent activity of Neem oil against $R$. dominica

Among the tested concentrations highest repellency was observed in $3 \%$ concentration of essential oil i.e. 87.51 (Table 1), $R$. dominica at $1 \%$ and $2 \%$ showed less repellent activity as compared to $3 \%$ i.e. 80.66 and 90.06 , respectively.

Table.1 Repellency of Neem oil against $R$. dominica

\begin{tabular}{|l|c|c|c|r|r|r|}
\hline \multirow{2}{*}{ Concentration } & \multicolumn{3}{|l|}{$\begin{array}{l}\text { Percent repellency of Neem oil against } \boldsymbol{R} . \\
\text { dominica }\end{array}$} & $\begin{array}{l}\text { Mean } \\
\text { repellency }\end{array}$ & $\begin{array}{l}\text { Repellency } \\
\text { class }\end{array}$ \\
\cline { 2 - 6 } & 30min & \multicolumn{1}{|c|}{ 60min } & $90 \mathrm{~min}$ & $120 \mathrm{~min}$ & & \\
\hline $\mathbf{1 \%}$ & 66.67 & 82.08 & 84.53 & 88.66 & 80.49 & $\mathrm{~V}$ \\
$\mathbf{2 \%}$ & 77.45 & 88.66 & 81.48 & 92.79 & 85.10 & $\mathrm{~V}$ \\
$\mathbf{3 \%}$ & 86.70 & 88.66 & 74.67 & 100.00 & 87.51 & $\mathrm{~V}$ \\
\hline
\end{tabular}

Table.2 Repellency of Neem oil against T. castaneum

\begin{tabular}{|c|c|c|c|c|c|c|}
\hline \multirow[t]{2}{*}{ Concentration } & \multicolumn{4}{|c|}{$\begin{array}{l}\text { Percent repellency of Neem oil against } T \text {. } \\
\text { castaneum }\end{array}$} & \multirow[t]{2}{*}{$\begin{array}{l}\text { Mean } \\
\text { repellency }\end{array}$} & \multirow[t]{2}{*}{$\begin{array}{l}\text { Repellency } \\
\text { class }\end{array}$} \\
\hline & $30 \mathrm{~min}$ & $60 \mathrm{~min}$ & $90 \mathrm{~min}$ & $120 \mathrm{~min}$ & & \\
\hline $1 \%$ & 84.03 & 86.48 & 92.36 & 90.61 & 88.37 & $\mathrm{~V}$ \\
\hline $2 \%$ & 92.79 & 94.54 & 96.49 & 96.49 & 95.08 & $\mathrm{~V}$ \\
\hline $3 \%$ & 94.74 & 96.49 & 100.00 & 100.00 & 97.81 & V \\
\hline
\end{tabular}

Repellent activity of neem oil against $T$. castaneum

All the tested concentrations against $T$. castaneum showed good results (Table 2) and 88.37, 95.08 and 97.81 percent repellency was observed at $1 \%, 2 \%$ and $3 \%$ respectively.

The results of the above two studies indicate that the plant essential oils are as effective as chemical grain protectants for protection of grains.

\section{References}

Abbott, W.S. 1925. A method of computing the effectiveness of an insecticide. $J$. Econ. Entomol., 18, 266-267.

Ahmed, S. and Grainge, M. 1985. The use of indigenous plant resources in rural development: potential of the neem tree. International Journal of Development Technology 3, 123-130.

Bouda, H.; Tapondjou, L. A.; Fontem, D.A. and Gumedzoe, M. Y. D. 2001. Effect of essential oils from leaves of Ageratum conyzoides, Lantana camara and Chromolaena odorata on the mortality of Sitophilus zeamais (Coleoptera, Curculionidae). J Stored Prod. Res., 37(2): 103-109.

Chanbang, Y.; Arthur, F.H.; Wilde, G.E. and Throne, J.E. 2007. Efficacy of diatomaceous earth to control Rhyzopertha dominica (F.) (Coleoptera: Bostrichidae) in rough rice: impacts of temperature and relative humidity. Crop Protection 26, 
923-929.

Collins, P.J.; Daglish, G.J.; Pavic, H.; Lambkin, T.M. and Kapittke, R. 2002. Combating strong resistance to phosphine in stored grain pests in Australia. In: Wright, E.J., Banks, H.J., Highley, E. (Eds.), Stored Grain in Australia 2000. Proceedings of the Australian Postharvest

Grainge, M.; Ahmed, S.; Mitchell, W.C. and Hylin, J.W. 1985. Plant Species Reportedly Possessing Pest Control Properties, an EWC/UN data base. Resource Systems Institute, EWC Honolu. College of Tropical Agriculture and Human Resources, University of Hawaii.

Roy, B.; Amin, R. and Uddin, M.N. 2005. Leaf extracts of Shiyalmutra (Blumea lacera) as botanical insecticides against lesser grain borer and riceweevil. J. Biol. Sci., 5, 201-204.

Sinha, R. N. and Watters, F. L. 1985. Insect pests of flour mills, Grain elevators and feed mills and Their control. Agriculture Canada, Publication 1776, Ottawa, ON, Canada.

Stoll, G. 1988. Natural Crop Protection Based on Local Farm Resources in the Tropics and Sub-tropics, Third
Edition. Weikersheim, Margraf Publishers Scientific Books, Germany, p. 188.

Talukdar, F.A. and Howse, P.E. 1993. Deterrent and insecticidal effect of extract of pithraj, Aphanamixis polystacha against Tribolium castaneum. J. Chem. Ecel., 19,24632471.

Taylor, R. W. D. 1989. Phosphine- a major fumigant at risk. International Pest Control, 31, 10-14.Technical Conference, Adelaide, 1-4 August 2000. CSIRO Stored Grain Research Laboratory, Canberra, Australia, pp. 109-112.

Vayias, B.J.; Athanassiou, C.G.; Milonas, D.N. and Mavrotas, C. 2010. Persistence and efficacy of spinosad on wheat, maize and barley grains against four major stored product pests. Crop Prot. 29, 496e505.

Vietmeyer, N.D. 1992. Neem: a tree for solving global problems. Report of an ad hoc panel of the Board on Science and Technology for International development. National Research Council, Washington D.C., U.S.A., National Academy Press, p. 141.

\section{How to cite this article:}

Rashmi Joshi, Neeta Gaur, Ashish Devrani and Mritunjoy Barman. 2019. Repellency of Neem Oil against Red Rust Flour Beetle, Tribolium castaneum Herbst, (Coleoptera:Tenebronidae) and Lesser Grain Borer, Rhyzopertha dominica(Fabricius) (Coleoptera: Bostrichidae). Int.J.Curr.Microbiol.App.Sci. 8(01): 521-524. doi: https://doi.org/10.20546/ijcmas.2019.801.057 